\title{
Head and Neck Cancer: Changes in Artrokinematic Parameters of Neck and Swallowing Function after Radiotherapy
}

\author{
Selen SEREL ${ }^{1}$, Numan DEMIR ${ }^{1}$, A. Ayşe KARADUMAN ${ }^{1}$, Mustafa CENGIZ ${ }^{2}$, Yavuz YAKUT ${ }^{1}$ \\ ${ }^{1}$ Hacettepe University, Faculty of Health Sciences, Department of Physiotherapy and Rehabilitation \\ ${ }^{2}$ Hacettepe University, Faculty of Medicine, Department of Radiation Oncology, Ankara, TURKEY
}

\begin{abstract}
The study aimed to show the changes on artrokinematic parameters of the neck and swallowing function after radiotherapy (RT) in head and neck cancer (HNC) patients. The fourty patients with HNC have been evaluated before, 1 and 3 months after RT. The posture, normal joint movement, muscle strength and endurance of the neck were evaluated as artrokinematic parameters. The clinical and radiological swallowing function evaluations were also done. Mean age of patients were $53,22 \pm 10,92$ years. Head anterior tilt, kyphosis and shoulder protraction were more in the 3rd month after RT in posture analysis $(p<0.001)$. The neck flexion, lateral flexion and rotation limitations have increased $(p<0.001)$, neck muscle strength and endurance have gradually decreased $(p<0,001)$ after RT. At the same time, swallowing phases have been adversely affected after RT with all these side effects $(p<0.001)$ and the severity of aspiration in all consistencies has increased gradually $(p<0.05)$. As a result, $R T$ starts to show its negative effects from the early period of cancer treatment. Unlike other studies, we concluded that RT affects head and neck structures negatively and these describes how RT affects swallowing function. So it is highly important to include head and neck structure mobility, strength and endurance assessments and exercises in swallowing rehabilitation.
\end{abstract}

Keywords: Head and neck cancer, Radiotherapy, Swallowing, Neck structures, Dysphagia

\section{ÖZET}

Baş Boyun Kanseri: Radyoterapi Sonrası Boyun Artrokinematik Parametreleri ve Yutma Fonksiyonundaki Değişiklikler Çalışmanın amacl; baş boyun kanserli (BBK) hastalarda radyoterapi (RT) sonrası boyun artrokinematik parametreleri ve yutma fonksiyonundaki değişiklikleri göstermektir. BBK'll 40 hasta RT öncesi, sonrası 1 ve 3. aylarda değerlendirildi. Artrokinematik parametreler olarak boyun postür, normal eklem hareketi, kas kuvvet ve enduransı değerlendirildi. Klinik ve radyolojik yutma fonksiyon değerlendirmeleri de yapıldı. Hastaların yaş ortalaması 53,22 $\pm 10,92$ yıldı. Postür analizinde baş anterior tilti, kifoz ve omuz protraksiyonu RT sonrası 3. ayda daha fazla idi ( $p<0.001)$. RT sonrası boyun fleksiyon, lateral fleksiyon ve rotasyon limitasyonları arttı $(p<0.001)$, boyun kas kuvvet ve enduransı giderek azaldı $(p<0.001)$. Aynı zamanda RT sonrası tüm bu yan etkilerle birlikte yutma fazları kötü yönde etkilendi $(p<0.001)$ ve tüm kıvamlarda aspirasyon şiddeti giderek arttı $(p<0.05)$. Sonuç olarak RT erken dönemden itibaren olumsuz etkilerini göstermeye başlamaktadır. Diğer çalışmalardan farklı olarak RT'nin baş ve boyun yapılarını olumsuz yönde etkilediği ortaya konuldu ve bu da RT'nin yutma fonksiyonunu nasıl etkilediği açıklamaktadır. Bu yüzden yutma rehabilitasyonuna baş boyun yapı hareketlilik, kuvvet ve endurans değerlendirme ve egzersizlerini dahil etmek çok önemlidir.

Anahtar Kelimeler: Baş boyun kanseri, Radyoterapi, Yutma, Boyun yapıları, Disfaji 


\section{INTRODUCTION}

The treatment types of the head and neck cancers (HNC) will be surgical removal of the tumor, radiotherapy (RT), chemotherapy (CT) or a combination of these procedures. Various degrees of dysphagia may occur during and after diagnosis and treatment. ${ }^{1}$

The relationship between structures involved in swallowing function is impaired greatly after treatment in HNC patients. Surgical removal results in a lot of swallowing problems due to lack of anatomical structures. Changes in the muscle tissue after RT occur and continue for a long time. ${ }^{2}$ These changes result in loss of normal muscle cells and it leads to stiffen soft tissue and decrease in muscle strength. ${ }^{3}$ The effects of RT on mobility and strength of oropharyngeal structures were demonstrated in previous studies. ${ }^{4-10}$ Optimal rehabilitation programme includes not only oropharyngeal exercises which are focus on oropharyngeal mobility and strength but also neck mobility and strengthening exercises. Although we know the importance of head and neck structures mobility and strength in swallowing rehabilitation, there is no study to evaluate the artrokinematic characteristics of head and neck like posture, range of motion, strength and endurance after RT. So we tried to show the effects of these artrokinematic parameters on swallowing function by including them to swallowing evaluation.

RT may affect the artrokinematic characteristics of head and neck, and this may have severely negative effects on swallowing. Based on this idea, we aimed to show the changes on artrokinematic parametres of the neck and swallowing function after RT.

\section{PATIENTS AND METHODS}

The study included 45 individuals with HNC patients who had RT plan. Patients were evaluated before, 1 and 3 months after RT. Median age of patients was 56 (min: 20, max: 65) years. There were 33 males $(82.5 \%)$ and 7 females (17.5\%).

Patients who had swallowing problems due to other medical reasons and received RT before were not included in the study.
The study was approved by the Ethics in Research Committee of our institution.

Demographic and clinical information of patients which were obtained from them and their hospital records were noted. The information about patients included their age, gender, height, weight and diagnosis. The localization, degree, stage and pathology of tumor were also taken. And their treatment information which included the presence of surgery and $\mathrm{CT}$, duration and field of RT were noted.

Observarvational posture analysis, especially including vertebral column, head and neck was performed in standing position. Head anterior tilt, cervical flattening, kyphosis, protraction and height of the shoulders were examined in anterior and lateral planes. Postural changes were scored between 0-3. (0: normal, 1: mild deviation, 2: moderate deviation, 3: severe deviation). Normal range of motion (ROM), muscle strength and endurance of neck were also recorded. ROM measurements were taken in the direction of flexion, extention, lateral flexions and rotations with goniometer while patients were sitting upright on chair. Neck flexion in supine position, extention in prone position and lateral flexion in side lying position were measured with dynamometer (Lafayette MMT, Model 01160). Endurance assessment can be defined as how many times patients can do neck flexion, extension and lateral flexion in one minute period.

Clinical and radiological swallowing assessments were done. ${ }^{11}$ In clinical assessment, Swallowing Ability and Functional Evaluation (SAFE) was used. Its parameters are physical oromotor functions, oral and pharyngeal phase assessments. Swallowing was graded normal, mild, moderate and severe impairment in each parameters. In radiological assessment, videofluoroscopic swallowing evaluation(VFSE) were done with three consistency of food (liquid-pudding-biscuit). In statistical analysis, we used $5 \mathrm{ml}$ volume of each consistencies which provide to monitor swallowing physiology more effective. ${ }^{12}$ Oral, pharyngeal and esophageal swallowing physiologies and residue after swallowing were evaluted with VFSE. Some subparameters like tongue retraxion, delay in triggering the swallowing reflex, hyolaryngeal elevation, airway closure, aspiration, esophageal motility disorder were also assessed. Each parameters were scored 
between 0-3 (0: normal, 1: mild impairment, 2: moderate impairment, 3 : severe impairment). In residue scoring, 0 was used for no residue, 1 was mild, 2 was moderate and 3 was severe residue. Penetration- Aspiration Scale (P-AS) was used for determining the penetration aspiration severity. ${ }^{13}$

\section{Statistical Analysis}

Statistical analyses were performed using the SPSS software version 15 . The variables were investigated using the visual (histograms, probability plots) and analytical methods (Kolmogorov-Simirnov/Shapiro-Wilk's test) to determine whether or not they are normally distributed. Descriptive analyses were presented using medians and interquartile range (IQR) fort he non-normally distributed and ordinal variables. Friedman tests were conducted to test whether there is a significant change. The Wilcoxon test was performed to test the significance of pairwise differencesto adjust for multipl comparisons. An overall 5\% type-I error level was used to infer statistical significance.

\section{RESULTS}

The study included $45 \mathrm{HNC}$ patients, of whom 1 was exitus, 2 did not completed their treatment and 2 did not come their controls. So the study was completed with 40 patients.

Median age of patients was 56 (min: 20, max: 65) years. There were 33 males $(82.5 \%)$ and 7 females $(17.5 \%)$. Table 1 summarizes tumor characteristics.

All cases underwent RT, of whom 33 (82.5\%) received concomitant chemoterapy and radiotherapy. Two (5\%) patients underwent surgery for primary tumor, $24(60 \%)$ underwent surgery for primary tumor with neck dissection and 14 (35\%) had no surgery.

RT was delivered to primary tumor and/or all lymphatics. All cases received RT to primary tumor site. Beside the primary site, 27 patients received additional RT to right neck, 26 to left neck and 28 to supraclavicular fossa. Median daily dose was 180 cGy (min: 180, max: 230). Median RT dose to primary tumor site was 6000 cGy (min: 5580, max: 7020), to neck field was 5400 cGy (min: 5000, max: 6000). And dose was increased up to 7000 cGy if there was lymp node involvement.

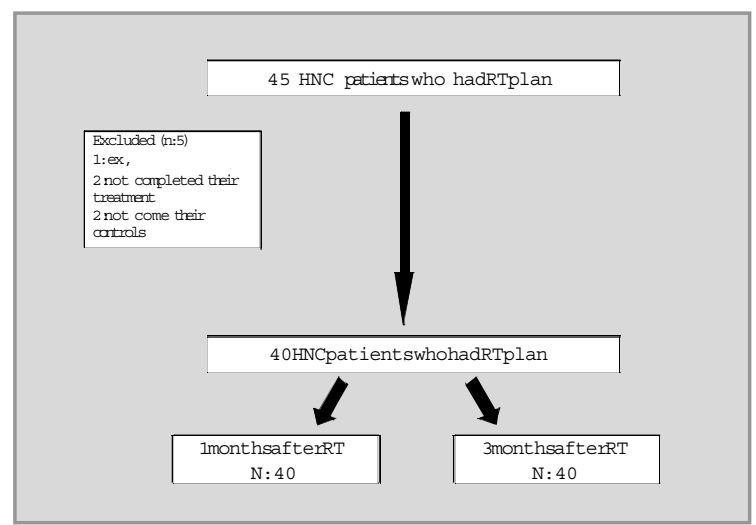

Figure 1. Flowchart of patients $(\mathrm{HNC}=$ head and neck cancers)

\begin{tabular}{|ll|}
\hline Table 1. Tumor characteristics & \\
\hline Tumor site & $\mathbf{n}(\%)$ \\
\hline Larynx & $20(50 \%)$ \\
Nasopharynx & $5(12.5 \%)$ \\
Tongue & $5(12.5 \%)$ \\
Tonsil & $3(7.5 \%)$ \\
Retromolar trigone & $2(5 \%)$ \\
Parotid & $2(5 \%)$ \\
Lips & $1(2.5 \%)$ \\
Tongue base & $1(2.5 \%)$ \\
Hypopharynx & $1(2.5 \%)$ \\
Tumor Degree & \\
Undifferentiated & $3(7.5 \%)$ \\
Less differentiated & $1(2.5 \%)$ \\
Moderate differentiated & $29(72.5 \%)$ \\
High differentiated & $7(17.5 \%)$ \\
Tumor pathology & \\
Squamous cell carcinoma & $11(27.5 \%)$ \\
Adenoid carcinoma & $34(85 \%)$ \\
Acinic cell carcinoma & $5(12.5 \%)$ \\
III & $1(2.5 \%)$ \\
IIA & \\
\hline & $5(12.5 \%)$ \\
\hline II & $1(2.5 \%)$ \\
\hline
\end{tabular}




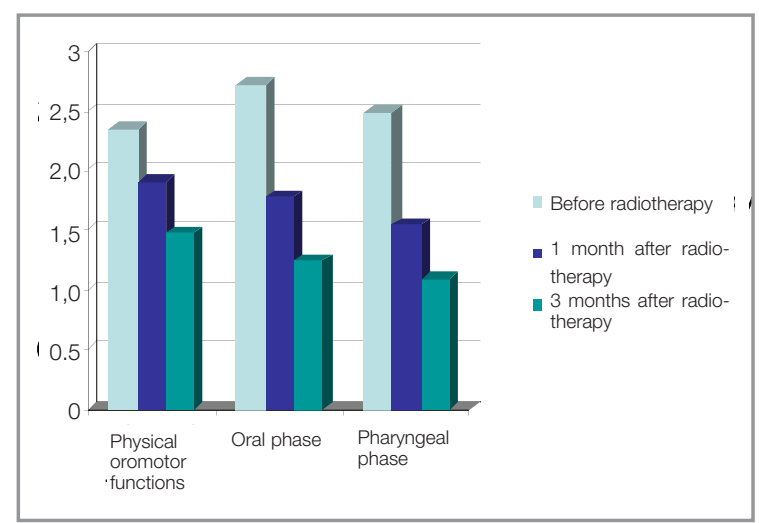

Figure 2. SAFE scores before, 1 and 3 months after radiotherapy

In clinical swallowing evaluation, physical oromotor functions, oral and pharyngeal phase of SAFE were gradually worsened towards the third month $(\mathrm{p}<0,001)$. SAFE scores before, 1 and 3 months after RT were shown at Figure 2.

VFSE results also supported these findings. Oral, pharyngeal, esophageal phase impairments, amount of residue and total swallowing impairment score were all increased $(\mathrm{p}<0,001)$. Tongue retraxion, delay in triggering swallowing reflex, hyolaryngeal elevation, esophageal motility disorder, airway closure in liquids and pudding consistencies were gradually worsened towards the third month $(\mathrm{p}<$ $0,001)$. In parallel with these results, aspiration severity in liquids, pudding and biscuit consistencies increased after RT $(\mathrm{p}<0,05)$. Distribution of pati- ents according to aspiration status was summarized in Table 2.

Aspiration severity in liquids and pudding consistencies according to P-AS were gradually increased after RT $(\mathrm{p}<0,001)$. There was no difference between 1 and 3 months after RT(p>0,05), but there is an increase in aspiration severity in direction to 1 and 3 months after RT than before RT in biscuit consistencies $(\mathrm{p}<0,001)$.

Head anterior tilt and kyphosis were gradually increased after RT $(\mathrm{p}<0,001)$. There was no difference between 1 and 3 months after RT(p>0,05), but there is an increase in shoulder protraxion in direction to 1 and 3 months after RT than before RT ( $\mathrm{p}<$ $0,001)$. There was no significant difference in cervical lordosis and shoulder height before, 1 and 3 months after RT ( $p>0,05)$.

Changes in ROM of neck flexion, lateral flexion and rotation 1 and 3 months after RT were significantly worse when compared to pre-RT status. Neck left lateral flexion and rotation limitation were gradually increased after $\mathrm{RT}(\mathrm{p}<0,001)$. There was no difference between 1 and 3 months after $\mathrm{RT}(\mathrm{p}>0,05)$, but there is an increase in neck flexion, right lateral flexion and rotation limitation in direction to 1 and 3 months after RT than before RT $(\mathrm{p}<0,001)$.

Neck flexion strength, neck flexion, extention and lateral flexion endurances were gradually decreased after RT $(\mathrm{p}<0,001)$ (Table 3$)$.

\begin{tabular}{|lll|}
\hline Table 2. Aspiration status before, 1 and 3 months after radiotherapy \\
\hline ASPIRATION & + & \\
\hline LIQUID- before RT & $2(5 \%)$ & $38(95 \%)$ \\
LIQUID- 1 month after RT & $8(20 \%)$ & $32(80 \%)$ \\
LIQUID- 3 months after RT & $9(22.5 \%)$ & $31(77.5 \%)$ \\
PUDDING- before RT & $-(0 \%)$ & $40(100 \%)$ \\
PUDDING-1 month after RT & $7(17.5 \%)$ & $33(82.5 \%)$ \\
PUDDING-3 months after RT & $7(17.5 \%)$ & $33(82.5 \%)$ \\
BISCUIT- before RT & $-(0 \%)$ & $40(100 \%)$ \\
BISCUIT-1 month after RT & $7(17.5 \%)$ & $33(82.5 \%)$ \\
BISCUIT-3 months after RT & $7(17.5 \%)$ & $33(82.5 \%)$ \\
\hline
\end{tabular}




\begin{tabular}{|c|c|c|c|c|}
\hline & $\begin{array}{l}\text { Before RT } \\
\text { Mean } \pm \text { SD }\end{array}$ & $\begin{array}{l}1 \text { months after RT } \\
\text { Mean } \pm S D\end{array}$ & $\begin{array}{l}3 \text { months after RT } \\
\text { Mean } \pm S D\end{array}$ & $\mathbf{p}$ \\
\hline \multicolumn{5}{|l|}{ Neck ROM limitations } \\
\hline Neck flexion & $10,43 \pm 6,72$ & $14,18 \pm 6,62$ & $15,38 \pm 6,19$ & $<0,001$ \\
\hline Neck extension & $17,05 \pm 9,69$ & $18,53 \pm 8,05$ & $19,43 \pm 7,59$ & 0,079 \\
\hline Neck right lateral flexion & $11,25 \pm 8,15$ & $14,15 \pm 7,86$ & $15,13 \pm 6,78$ & $<0,001$ \\
\hline Neck left lateral flexion & $10,88 \pm 7,64$ & $14,25 \pm 6,44$ & $15,28 \pm 6,50$ & $<0,001$ \\
\hline Neck right rotation & $1,53 \pm 3,99$ & $3,83 \pm 6,51$ & $4,7 \pm 7,13$ & $<0,001$ \\
\hline Neck left rotation & $2,45 \pm 5,05$ & $3,35 \pm 5,52$ & $5,18 \pm 8,15$ & $<0,001$ \\
\hline \multicolumn{5}{|l|}{ Neck muscle strength } \\
\hline Neck flexion & $4,85 \pm 2,05$ & $3,77 \pm 1,78$ & $2,91 \pm 1,58$ & $<0,001$ \\
\hline Neck extension & $8,43 \pm 1,28$ & $8,30 \pm 1,24$ & $8,25 \pm 1,28$ & 0,146 \\
\hline Neck right lateral flexion & $6,86 \pm 2,19$ & $6,80 \pm 2,23$ & $6,71 \pm 2,12$ & 0,137 \\
\hline Neck left lateral flexion & $6,38 \pm 2,12$ & $6,35 \pm 2,12$ & $6,04 \pm 2,11$ & 0,350 \\
\hline \multicolumn{5}{|l|}{ Neck muscle endurance } \\
\hline Neck flexion & $26,8 \pm 9,25$ & $21,23 \pm 7,30$ & $17,63 \pm 6,89$ & $<0,001$ \\
\hline Neck extension & $32,9 \pm 10,64$ & $28,18 \pm 7,09$ & $26,38 \pm 7,19$ & $<0,001$ \\
\hline Neck right lateral flexion & $29,73 \pm 8,66$ & $25,65 \pm 7,39$ & $23,15 \pm 6,69$ & $<0,001$ \\
\hline Neck left lateral flexion & $31,03 \pm 7,85$ & $25 \pm 7,48$ & $23,4 \pm 6,71$ & $<0,001$ \\
\hline
\end{tabular}

\section{DISCUSSION}

Our study showed that swallowing function of HNC patients was affected negatively after RT in early period. The aspiration severity was gradually increased. Artrokinematic parameters were also affected negatively. Postural changes in head anterior tilt, kyphosis and shoulder protraxion were increased. Neck flexion, lateral flexion and rotation limitations were increased while neck flexion strength, neck flexion, extension and lateral flexion endurances were decreased.

Oral and pharyngeal swallowing disorders were demonstrated after RT in HNC patients in many studies. ${ }^{2.914-17}$ Decreased tongue mobility and strength, impairment in bolus preparation and transport, increased oral residue were described as oral phase disorders ${ }^{15,18,19}$ Delayed triggering swallowing reflex, impairment in velopharyngeal closure, decreased tongue base retraxion, pharyngeal contraction, hyolaryngeal elevation, airway closure, upper esopha- geal sphincter (UOS) opening and increased residue in tongue base, vallecula, pharynx and pyriform sinus were determined as phryngeal disorders after RT. ${ }^{3,14,15,20-23}$ In a study, decreased tongue base retraxion and hyolaryngeal elevation 1 month after CRT, delayed triggering swallowing reflex, impairment in airway closure 3 months after CRT, decreased UOS opening 6 and 12 months after CRT were found. They stated that these results related to decreased oral intake. ${ }^{24}$ Our results support the literature. In our study, tongue base retraxion, hyolaryngeal elevation decreased, delayed triggering swallowing reflex and residue increased. So severity of oral, pharyngeal and esophageal swallowing disorders were gradually increased after RT.

In VFSE, we determined that airway closure were gradually worsened and aspiration severity increased after RT. Aspiration rates before, 1 and 3 months after RT is respectively, 5\%,20\%, 22,5\% in liquids, $0 \%, 17,5 \%, 17,5 \%$ in puding and biscuit 
consistencies. These results were parallel with literature. In a study of 43 patients with larynx cancer who received RT/CRT, aspiration was seen in 54\% (12/22) of patients in CRT group, 33\% (7/21) of patients in RT group (8) . In another study of 64 patients who received CRT, when aspiration rate was $17 \%$ before treatment, it increased to $59 \% 2$ months (1-10 month) after treatment. ${ }^{25}$ It is clear that aspiration severity increases with abnormalities in oropharyngeal structures. These abnormalities of anatomical structures due to RT/CRT can be reduced by reorganization the treatment modalities. But it is not always possible. So HNC patients should be regularly followed for the aspiration risk from the period prior to RT.

VFSE is described as the gold standard in swallowing evaluation in studies. ${ }^{26}$ After swallowing evaluation, exercise programmes which focus on neck mobility and strengthening are used. Although we know the importance of head and neck structures mobility and strength in swallowing rehabilitation, classical swallowing evaluations do not include posture analysis, ROM, strength and endurance assessments. So we tried to emphasize the effects of these artrokinematic parameters on swallowing function by including them to swallowing evaluation. In posture analysis, head anterior tilt and kyphosis were gradually increased after RT. There was no difference between 1 and 3 months after RT, but there is an increase in shoulder protraxion in direction to 1 and 3 months after RT than before RT. Postural changes were thought to occur due to decreased mobility, strength and endurance of the region or the patients efforts to protect the region during the disease period. Protective behaviour of patients when they come for evaluation after RT supported this hypothesis. ROM, muscle strength and endurance of neck also adversely affected. Neck left lateral flexion and rotation limitation were gradually increased after RT. There was no difference between 1 and 3 months after RT, but there is an increase in neck flexion, right lateral felxion and rotation limitation in direction to 1 and 3 months after RT than before RT. Neck flexion strength, neck flexion, extention and lateral flexion endurances were gradually decreased after RT. Thus, changes in neck posture, , range of motion, muscle strength and endurance after RT was found unlike other studies. We think that these dramatic changes have a significant impact on swallowing function. And postural changes and loss of strength also causes pain and excessive effort during activity. So neck ROM, strength and endurance assessments should be done before, during and after RT. This provide us to prevent negative effects of RT from the early period. Physiotherapy methods are very important to cope with these negative side effects.

Further studies with more patients or long follow up may be planned. New groups may be created according to diagnosis and RT doses. And how swallowing function and neck region will be affected can be described. Changes in long term can also be determined.

These results demonstrated that RT affects swallowing function negatively in early period. In addition, artrokinematic parameters of neck are also worsened after RT. If problems do not handle in early period, more problems may occur in the future. So if it is possible, swallowing assessments which include the assessments of head and neck artrokinematic parameters should be done before RT and possible impairments can be determined and prevented. We concluded that an important development in swallowing ability, nutritional status and also life quality of the patients with early intervention can be provided.

\section{REFERENCES}

1. Manikantan K, Khode S, Sayed SI, et al. Dysphagia in head and neck cancer. Cancer Treatment Rev 35: 724-732, 2009.

2. Wang TG, Chang YC, Chen WS, et al. Reduction in hyoid bone forward movement in irradiated nasopharyngeal carcinoma patients with dysphagia. Arch Phys Med Rehabil 91: 926-931, 2010.

3. Logemann JA, Rademaker AW, Pauloski BR, et al. Site of disease and treatment protocol as correlates of swallowing function in patients with head and neck cancer treated with chemoradiation. Head \& Neck 28: 64-73, 2006.

4. Rinaldo A, Ferlito A. Open supraglottic laryngectomy. Acta Otolaryngol 124: 768-771, 2004.

5. Pauloski BR, Rademaker AW, Logemann JA, et al. Speech and swallowing in irradiated and nonirradiated postsurgical oral cancer patients. Head Neck Surg 118: 616-624, 1998. 
6. Zuydam AC, Lowe D, Brown JS, et al. Predictors of speech and swallowing function following primary surgery for oral and oropharyngeal cancer. Clin Otolaryngol 30: 428-437, 2005.

7. Dworkin JP, Hill SL, Stachler RJ, et al. Swallowing function outcomes following nonsurgical therapy for advanced-stage laryngeal carcinoma. Dysphagia 21: 66-74, 2006.

8. Eisbruch A, Lyden T, Bradford CR, et al. Objective assessment of swallowing dysfunction and aspiration after radiation concurrent with chemotherapy for head-and-neck cancer. Int $J$ Radiat Oncol Biol Phys 53: 23-28, 2002.

9. Logemann JA, Pauloski BR, Rademaker AW, et al. Swallowing disorders in the first year after radiation and chemoradiation. Head \& Neck 30: 148-158, 2008.

10. Carrara-de Angelis E, Feher O, Barros AP, et al. Voice and swallowing in patients enrolled in a larynx preservation trial. Head Neck Surg, 129: 733-738, 2003.

11. Ott DJ,Pikna LA. Clinical and videofluoroscopic evaluation of swallowing disorders. AJR 161: 507-513, 1993.

12. Logemann JA. Evaluation and treatment of swallowing disorders. 2nd edition. Austin, Texas, PRO-ED,1998: 169-185.

13. Rosenbek JC, Robbins JA, Roecker EB, et al. A penetration-aspiration scale. Dysphagia 11: 93-98, 1996.

14. Nguyen NP, Smith HJ, Sallah S. Evaluation and management of swallowing dysfunction following chemoradiation for head and neck cancer. Otolaryngol Head Neck Surg 15: 130-133, 2007.

15. Hughes PJ, Scott PM, Kew J, et al. Dysphagia in treated nasopharyngeal cancer. Head \& Neck 22: 393397, 2000.

16. Bleier BS, Levine MS, Mick R, et al. Dysphagia after chemoradiation: analysis by modified barium swallow. Otorinolaringologie 116: 837-841, 2007.

17. Lazarus CL, Logemann JA, Pauloski BR, et al. Swallowing and tongue function following treatment for oral and oropharyngeal cancer. JSLHR 43: 1011-1023, 2000.

18. Lazarus CL, Logemann JA, Pauloski BR. Effects of radiotherapy with or without chemotherapy on tongue strength and swallowing. Head\& Neck 29: 632-637, 2007.

19. Smith RV, Kotz T, Beitler JJ, et al. Long-term swallowing problems after organ preservation therapy with concomitant radiation therapy and intravenous hydroxyurea: initial results. Otolaryngol Head Neck Surg 126: 384-389, 2000.

20. Nguyen NP, Frank C, Moltz CC, et al. Aspiration rate following chemoradiation for head and neck cancer: an underreported occurrence. Radiother Oncol 80: 302-306, 2006.
21. Pauloski BR, Rademaker AW, Logemann JA, et al. Relationship between swallow motility disorders on videofluorography and oral intake in patients treated for head and neck cancer with radiotherapy with or without chemotherapy. Head \& Neck 28: 1069-1076, 2006.

22. Nguyen NP, Smith HJ, Moltz CC, et al. Prevalence of pharyngeal and esophageal stenosis following radiation for head and neck cancer. Otolaryngol Head Neck Surg 37: 219-224, 2008.

23. Graner DE, Foote RL, Kasperbauer JL, et al. Swallow function in patients before and after intra-arterial chemoradiation. Laryngoscope 113: 573-579, 2003.

24. Ishida R, Palmer JB, Hiiemae KM. Hyoid motion during swallowing: factors affecting forward and upward displacement. Dysphagia 17: 262-272, 2002.

25. Chang YC, Chen SY, Lui LT, et al. Dysphagia in patients with nasopharyngeal cancer after radiation therapy: a videofluoroscopic swallowing study. Dysphagia 18: 135-143, 2003.

26. Nguyen NP, Moltz CC, Frank C, et al. Evolution of chronic dysphagia following treatment for head and neck cancer. Oral Oncol 42: 374-380, 2006.

\section{Correspondence}

Dr. Selen SEREL

Hacettepe Üniversitesi

Sağllkk Bilimleri Fakültesi

Fizyoterapi ve rehabilitasyon Bölümü

Sıhhiye, ANKARA / TURKEY

Tel: (+90.312) 3052525 - 156

Fax: (+90.312 3052012

e-mail: selen.serel@hacettepe.edu.tr 